\title{
Pengaruh Model Kolaboratif Berbasis Masalah terhadap Kepuasan Belajar Siswa Sekolah Dasar
}

\author{
Nina Nuramalina ${ }^{1}$, Imam Agus Basuki ${ }^{2}$, Suyono $^{2}$ \\ ${ }^{1}$ Pendidikan Dasar-Universitas Negeri Malang \\ ${ }^{2}$ Pendidikan Bahasa Indonesia-Universitas Negeri Malang
}

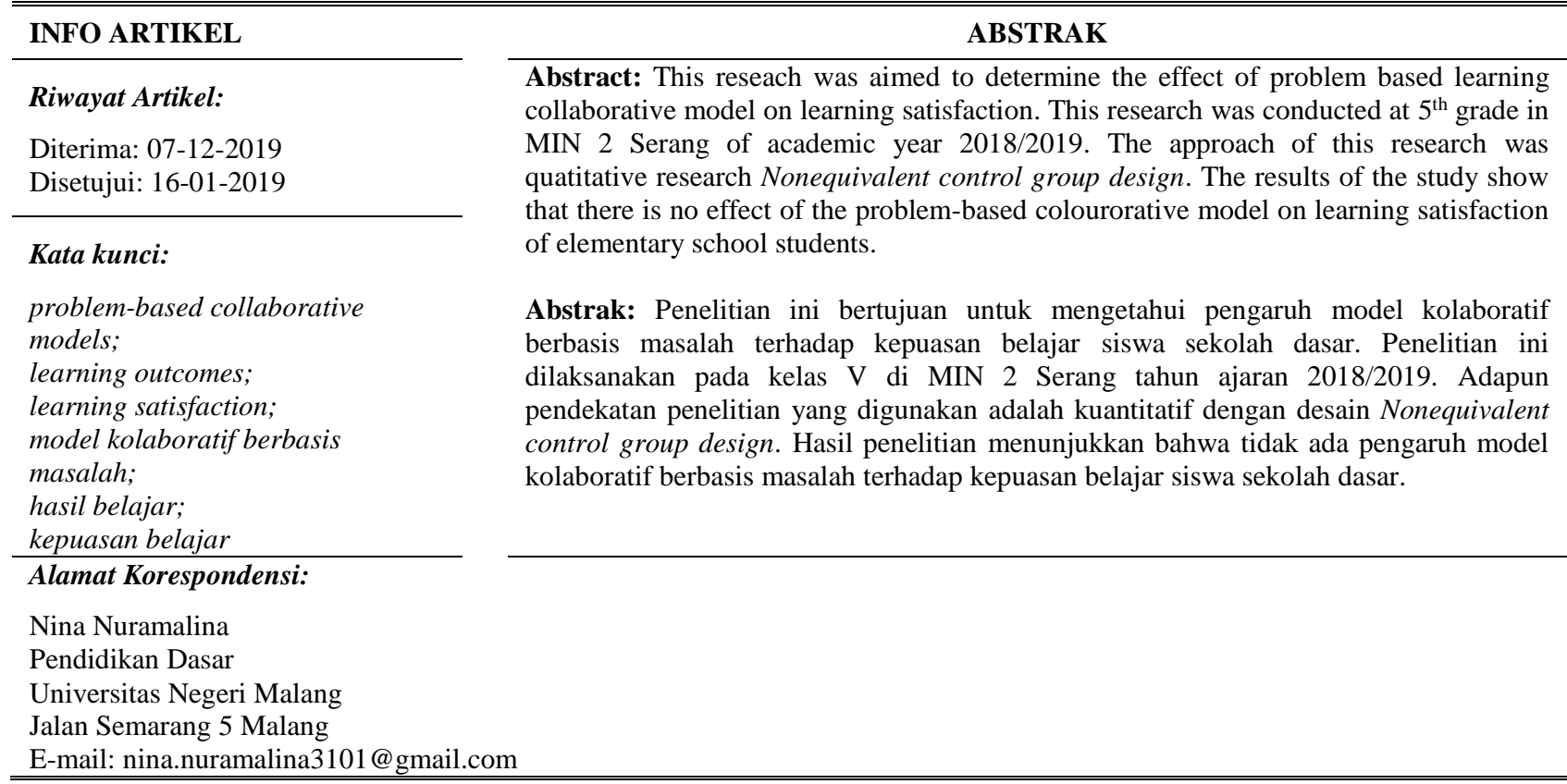

Kebermaknaan belajar sebagai suatu hasil pembelajaran ditandai dengan terjadinya suasana belajar yang PAKEM. Pembelajaran dapat berjalan dengan baik ketika setiap siswa mengalami belajar, mampu menyelesaikan tantangan, mencapai tujuan pembelajaran dan dapat mengkonstruk ilmu pengetahuannya. Oleh karena itu, usaha untuk mencapai tujuan pembelajaran dengan cara merancang pembelajaran dengan tepat dan memperhatikan karakteristik siswa sehingga kegiatan belajar dapat terlaksana. Perwujudan pembelajaran yang bermakna dengan memperhatikan fungsi dan tujuan pendidikan nasional yang tertera dalam UU RI No. 20 Tahun 2003 Pasal 3 menyebutkan bahwa fungsi pendidikan untuk mengembangkan kemampuan dan membentuk watak yang bermartabat serta bertujuan dalam rangka kemapuan potensi peserta didik. Dengan demikian, adanya usaha untuk meningkatkan kualitas pembelajaran dengan mengacu pada fungsi dan tujuan pendidikan.

Konteks belajar bermakna, guru memegang posisi penting untuk menciptakan suasana belajar aktif dan menyenangkan melalui penerapan model pembelajaran. Hasil penelitian menunjukkan bahwa konsistensi teoretis-praktis penggunaan model atau metode pembelajaran perlu dikedepankan dengan cara merencanakan dengan sebaik-baiknya serta berupaya menerapkannya secara optimal (Wedi, 2016). Hal ini menandakan perlunya pemilihan model pembelajaran untuk meningkatkan mutu pembelajaran. Salah satu model yang memiliki ciri-ciri tersebut dan diterapkan dalam pembelajaran yaitu model kolaboratif. Model kolaboratif adalah pola pembelajaran yang mengondisikan siswa bekerja bersama dalam kelompok untuk mencapai tujuan pembelajaran (Barkley, 2016). Model pembelajaran kolaboratif menekankan bahwa setiap individu atau siswa agar saling bekerjasama dalam kelompok belajar untuk membangun pengetahuan, menanamkan sikap dan mengasah keterampilan. Esensi dari model kolaboratif yaitu suatu pengetahuan dapat dibangun melalui usaha bersama oleh siswa dan guru melalui komunikasi yang baik.

Abraham Maslow mengungkapkan kebutuhan atau pencapaian tertinggi manusia yaitu dengan aktualisasi diri meliputi pemenuhan kebutuhan keberadaan diri melalui penggunaan kemampuan potensi secara maksimal (Globe,1999). Dalam rangka memenuhi kebutuhan siswa untuk aktualisasi diri perlu diberikan kesempatan untuk menggali potensi diri dalam pembelajaran. Model kolaboratif mencakup keseluruhan proses pembelajaran dimana siswa saling belajar membelajarkan dalam kelompok kecil untuk mencapai tujuan bersama. Kurikulum 2013 mengharapkan siswa memiliki kompetensi pada tiga dimensi yaitu keterampilan, sikap, dan pengetahuan. Kompetensi pada dimensi keterampilan siswa diharapkan memiliki keterampilan berpikir dan bertindak yang meliputi, kreatif, produktif, kritis, mandiri, kolaboratif, dan komunikatif dengan pendekatan ilmiah yang disesuaikan dengan tahap perkembangan siswa. 
Model kolaboratif dapat dipadukan dengan model pembelajaran lain tergantung kebutuhan dan tujuan belajar yang dicapai. Pada penelitian ini model kolaboratif dipadukan dengan pembelajaran berbasis masalah. Model kolaboratif membutuhkan kegiatan siswa untuk menganalisis suatu topik dan pembelajaran berbasis masalah membutuhkan kegiatan percobaan setelah mengumpulkan informasi yang telah didiskusikan. Hal tersebut menerangkan bahwa model kolaboratif dan pembelajaran berbasis masalah apabila dipadukan akan membentuk satu kesatuan yang dapat terlaksananya pengalaman belajar bersama yang bermakna.

Model kolaboratif berbasis masalah diaplikasikan dalam pembelajaran merupakan hal yang tepat karena memperhatikan kebutuhan belajar sesuai tingkat perkembangan siswa. Dilansir dari Majalah Seribu Guru bahwa siswa kelas tinggi berbeda kebutuhan dalam belajar dengan siswa kelas rendah. Siswa kelas tinggi mulai mengembangkan tingkat pengetahuannya dan mulai berargumen sederhana. Siswa mulai belajar memahami fakta-fakta alam di lingkungannya dan mulai berpikir kemengapaan yang terjadi di lingkungan sosial yang mereka temui dan memecahkan suatu permasalahan. Kebutuhan belajar tersebut dapat dipenuhi jika siswa mengalami pembelajaran.

Kegiatan kolaborasi memberikan peluang untuk melatih siswa belajar bekerja bersama-sama dan menghormati berbagai perbedaan yang dimiliki setiap siswa seperti latar belakang, pengalaman, kemampuan dan pandangannya (Warsono, 2016). Model kolaboratif memberikan manfaat dalam pembelajaran yaitu meningkatkan prestasi belajar. Hal ini telah dibuktikan berdasarkan hasil penelitian (Chandra, 2015) menunjukkan bahwa model kolaboratif dapat memengaruhi prestasi belajar siswa,meningkatkan hasil belajar kognitif, afektif, dan psikomotor. Hasil menunjukkan bahwa model pembelajaran kolaboratif berbasis masalah telah meningkat secara signifikan baik ranah afektif maupun ranah kognitif. Peningkatan yang terjadi akibat adanya komunikasi siswa dengan orang yang lebih mampu seperti guru atau teman sejawat. Penelitian yang dilakukan oleh (Uduafemhe, 2015) mengemukakan bahwa model pembelajaran kolaboratif lebih efektif dalam meningkatkan prestasi psikomotor siswa. Model ini mendorong siswa untuk berpendapat dan bertanya sehingga terjadi kegiatan belajar yang sesungguhnya sesuai tujuan. Pengalaman belajar yang terjadi membentuk dan mengasah keterampilan siswa. Berdasarkan hasil penelitian tersebut menjelaskan bahwa model kolaboratif memberikan manfaat dalam pembelajaran tidak hanya meningkatkan prestasi siswa dalam ranah kognitif, tetapi juga dapat meningkatkan ranah afektif dan ranah psikomotor.

Model pembelajaran kolaboratif memiliki keuntungan dan kelemahan. Keuntungan mengaplikasikan model kolaboratif yaitu bekerja bersama-sama lebih terasa ringan dibandingkan dengan bekerja sendiri. Hal tersebut sependapat dengan hasil penelitian (Balta, 2017) bahwa pembelajaran kolaboratif telah berpengaruh signifikan terhadap proses belajar siswa. Proses belajar yang mengondisikan berkolaborasi lebih terasa mudah dengan kegiatan berdiskusi memecahkan permasalahan dibandingkan bekerja individu. Berdiskusi dalam kelompok yang heterogen dapat menemukan beragam ide sehingga siswa dapat memperoleh pemahamnnya serta dapat mengembangkan keterampilan berpikir tingkat tinggi karena melibatkan proses berpikir siswa. Belajar bersama-sama dapat lebih membangun keberanian individu untuk berpendapat dan bertanya karena setiap siswa sama-sama memiliki rasa ingin tahu tentang suatu pengetahuan. Di sisi lain, kelemahan berkelompok yaitu terjadinya ketidakcocokan antar anggota kelompok. Ketidakcocokan tersebut mengakibatkan hambatan berjalannya pemerolehan pengetahuan yang berdampak terhadap hasil belajar (Barkley, 2016). Hasil wawancara yang dilakukan pada bulan Maret 2018 di MIN 2 Serang yaitu siswa dalam suatu kelompok mendominasi dari anggota yang lain sehingga menimbulkan ketidakcocokan. Ketidakcocokan tersebut mengakibatkan siswa sulit untuk belajar bersama dalam kelompok. Kelompok yang heterogen dibentuk dari berbeda latar belakang setiap siswa sehingga tidak jarang terjadi ketidakcocokan dalam proses kegiatan belajar kelompok.

Model kolaboratif diaplikasikan dalam pembelajaran memberikan manfaat terhadap pembelajaran yaitu meningkatkan hasil belajar siswa. Manfaat ini telah dibuktikan oleh (Sulistyawati \& Zuhdi, 2016) mengungkapkan bahwa menerapkan model kolaboratif dapat meningkatkan hasil belajar siswa. Hasil tersebut menunjukkan bahwa dengan penerapan model kolaboratif dapat memperoleh pengetahuan siswa dengan berinteraksi dalam pembelajaran sehingga siswa dapat memperoleh hasil yang diharapkan. Penelitian yang dilakukan oleh (Fleischmann \& Hutchison, 2012) menyatakan bahwa dengan penggunaan model kolaboratif terdapat respon yang positif dari siswa terlihat dari proses pembelajaran yang berjalan dengan menyenangkan dan hasil belajar yang meningkat. Sementara (Pogram et al., 2015) melaporkan bahwa model kolaboratif berbasis masalah dapat berpengaruh terhadap hasil belajar berupa aspek afektif dan aspek kognitif siswa. (Balta, 2017) menyatakan bahwa dengan menerapkan model kolaboratif berbasis masalah dapat memengaruhi proses belajar siswa terutama dalam konteks pemecah masalah secara berkolaborasi jika dibandingkan dengan belajar secara individu.

Implementasi model kolaboratif berbasis masalah yang melibatkan siswa aktif dalam belajar dapat menimbulkan kepuasan belajar siswa. Penelitian yang dilakukan oleh (Ünal \& Çakir, 2017) melaporkan bahwa siswa merasa puas dengan penggunaan lingkungan belajar yang dapat mendorong siswa berperan aktif dan dengan menggunakan model pembelajaran kolaboratif. Rasa kepuasan siswa sangat dirasakan melalui pengalaman belajar mereka yaitu pembelajaran yang dapat memotivasi belajar, mempelajari lebih banyak pengetahuan, pembelajaran yang aktif dan mengembangkan berbagai keterampilan sehingga timbul kesenangan dalam belajar. 
Proses pembelajaran masih banyak yang kurang memperhatikan kepuasan siswa dalam belajar. Kurangnya siswa mengalami bagian dari pembelajaran mengakibatkan ketidakpuasan dalam belajar. Pembelajaran yang seharusnya dialami setiap siswa, tetapi tidak sesuai dengan kebutuhan siswa dalam perkembangannya. Kepuasan belajar merupakan suatu sikap positif siswa terhadap proses pembelajaran yang dilaksanakan karena sesuai antara harapan dan kebutuhan dengan realita yang dirasakan (Sopiatin, 2010).

\section{METODE}

Metode penelitian eksperimen yang diterapkan dalam penelitian ini dengan desain non-equivalent control group design. Penelitian ini menerapkan dua kelompok penelitian yang diberikan treatment berbeda, meliputi kelompok eksperimen diberikan perlakuan dengan model kolaboratiff berbasis masalah dan kelompok kontrol melaksanakan pembelajaran secara konvensional dengan metode ceramah. Penelitian ini dilaksanakan di MIN 2 Serang pada kelas V dengan jumlah subjek 125 siswa pada tahun ajaran 2018/2019. Pengambilan sampel penelitian dengan non-random sampling karena mengikuti kelompok belajar yang telah terdapat sebelumnya.

Instrumen penelitian ini yaitu observasi dan angket. Observasi terdiri dari pengamatan kegiatan siswa dalam pembelajaran dan pengamatan kepuasan belajar siswa. Angket untuk mengukur kepuasan belajar siswa. Pengumpulan data pada penelitian ini menggunakan teknik non tes yaitu berupa observasi dan angket. Observasi yaitu digunakan untuk menyaksikan secara langsung informasi pada suatu kegiatan yang sedang berlangsung. Teknik angket yang diberikan berupa sejumlah pertanyaan untuk mendapatkan jawaban secara tertulis. Analisis data untuk menindaklanjuti data yang telah terkumpul dan dianalisis secara kuantitatif dengan menggunakan Mann-Whitney U Wilcoxon Test untuk menindaklanjuti data yang tidak berdistribusi normal.

\section{HASIL}

Deskripsi hasil penelitian mengenai pengaruh model kolaboratif berbasis masalah terhadap kepuasan belajar siswa. Perumusan desskripsi tersebut untuk mengetahui perbedaan antar kelompok yang telah diberikan perlakuan berbeda. Deskripsi pengaruh model kolaboratif berbasis masalah terhadap kepuasan belajar dijelaskan sebagai berikut. Hasil rata-rata kepuasan belajar pada kelompok ekperimen dapat diketahui bahwa hasil pretest dengan frekuensi 18 siswa memperoleh rata-rata 13,97 dengan persentase $58,1 \%$ berada pada kategori Puas. Hasil posttest dengan frekuensi 25 siswa memperoleh rata-rata 16,19 dengan persentase $80,6 \%$ berada pada kategori Puas. Berdasarkan hasil perhitungan tersebut, dapat disimpulkan bahwa perolehan nilai rata-rata posttest lebih besar dari nilai rata-rata pretest dan berada pada kategori puas.

Hasil rata-rata pada data kepuasan belajar siswa kelompok kontrol diketahui bahwa pada hasil pretest dengan frekuensi 23 siswa memperoleh rata-rata 14,06 dengan persentase 74,2\% berada pada kategori Puas. Hasil posttest dengan frekuensi 29 siswa memperoleh rata-rata 15,42 dengan persentase 93,5\% berada pada kategori Puas. Berdasarkan hasil perhitungan tersebut dapat disimpulkan bahwa nilai rata-rata posttest lebih besar dari nilai rata-rata pretest dan berada pada kategori puas. Berdasarkan paparan data kepuasan belajar tersebut dapat disajikan dengan tampilan Tabel 1.

Tabel 1. Analisis Data Kepuasan Belajar

\begin{tabular}{llcccc}
\hline Kelompok & Kepuasan Belajar & Frekuensi & Rata-Rata & Persentase & Kategori \\
\hline Eksperimen & Pretest & 18 & 13,97 & $58,1 \%$ & \\
& Posttest & 25 & 16,19 & $80,6 \%$ & \multirow{2}{*}{ Puas } \\
Kontrol & Pretest & 23 & 14,06 & $74,2 \%$ & \\
& Posttest & 29 & 15,42 & $93,5 \%$ & \\
\hline
\end{tabular}

Hasil analisis data dengan menggunakan Mann-Whitney U Wilcoxon Test diperoleh nilai signifikansi 0,089 > 0,05. Hal tersebut berarti $\mathrm{H}_{0}$ diterima dan hipotesis penelitian ditolak. Hasil yang telah diperoleh dapat ditarik kesimpulan bahwa tidak terdapat perbedaan kepuasan belajar siswa dalam pembelajaran dengan menggunakan Model Kolaboratif Berbasis Masalah dan pembelajaran secara konvensional. Setelah diketahui hasil rata-rata kedua kelompok dilakukan penghitungan $n$-gain untuk mengetahui peningkatan terhadap kepuasan belajar setelah diberikan perlakuan. Hasil penghitungan n-gain tertera pada Tabel 2.

Tabel 2. Hasil Penghitungan N-Gain Score Kepuasan Belajar

\begin{tabular}{lcccc}
\hline \multirow{2}{*}{ Kelompok } & \multicolumn{2}{c}{ Skor rata-rata Hasil Belajar } & \multirow{N}{*}{ N-Gain } & \multirow{2}{*}{ Kategori } \\
\cline { 2 - 5 } Eksperimen & Pretest & Posttest & & \\
Kontrol & 13,97 & 16,19 & $37 \%$ & Sedang \\
& 14,06 & 15,42 & $23 \%$ & Rendah \\
\hline
\end{tabular}


Berdasarkan pada Tabel 2 dapat diketahui bahwa pada kelompok eksperimen dengan rata-rata hasil pretest diperoleh 13,97 dan hasil posttest diperoleh 16,19 mengalami peningkatan sebesar 37\% berada pada kategori sedang. Pada kelompok kontrol dengan rata-rata hasil pretest diperoleh 14,06 dan hasil posttest diperoleh 15,42 mengalami peningkatan sebesar $23 \%$ berada pada kategori rendah.

\section{PEMBAHASAN}

Pada sub-bab ini membahas mengenai dua hal yaitu, pengaruh model kolaboratif berbasis masalah terhadap kepuasan belajar dan dinamika kelas.

\section{Kepuasan Belajar Belajar}

Hasil analisis menunjukkan bahwa skor posttest pada kelompok eksperimen memperoleh nilai rata-rata lebih besar dari pada kelompok kontrol. Hal ini belum dapat dikatakan sebagai kesimpulan dan perlu diuji hipotesis untuk mengetahui perbedaan dari kedua kelompok. Uji hipotesis menghasilkan bahwa tidak berpengaruh model kolaboratif berbasis masalah terhadap kepuasan belajar siswa. Hal tersebut terbukti berdasarkan perolehan nilai signifikansi 0,089 > 0,05. Dengan demikian berarti tidak ada perbedaan pengaruh antara model kolaboratif berbasis masalah dengan pembelajaran secara konvensional terhadap kepuasan belajar siswa. Hal ini berbeda dengan penelitian sebelumnya oleh (Hyun, Ediger, \& Lee, 2017) hasil menyatakan bahwa pembelajaran yang aktif memengaruhi kepuasan siswa secara positif dengan proses pembelajaran secara individu dan kelompok di ruang kelas. Faktor yang menjadi pengaruh terhadap kepuasan adalah pembelajaran yang aktif. Hasil penelitian tersebut bahwa pembelajaran yang melibatkan siswa berperan aktif yang dapat memengaruhi terhadap kepuasan belajar yang mana terdapat pengalaman dan pengetahuan yang didapat.

Penemuan hasil penelitian yang berbeda dilakukan oleh (Firoozi, Kazemi, \& Jokar, 2017) bahwa efikasi diri terhadap mengorganisasi komputer, harapan kinerja dan lingkungan belajar merupakan prediktor terbaik kepuasan belajar. Faktor siswa merasa puas dengan pembelajaran adalah fasilitas yang memadai dan lingkungan belajar yang sangat mendukung untuk kegiatan belajar. Dalam penelitian tersebut bawa efikasi diri merupakan variabel kognitif yang penting, secara signifikan dan positif berkorelasi dengan kepuasan belajar. Siswa dengan efikasi diri yang lebih tinggi mengekspos diri mereka lebih banyak ke komputer dan internet.

Penelitian ini selaras dengan penelitian (Choi, 2016) menghasilkan temuan bahwa strategi belajar kognitif seperti latihan, elaborasi, organisasi, dan pemikiran kritis tidak memiliki korelasi yang signifikan dengan kepuasan belajar siswa. Faktor yang menjadikan bahwa strategi kognitif tidak terdapat hubungan terhadap kepuasan belajar adalah strategi pembelajaran dengan struktur instruksional tidak sejalan dengan baik sehingga kegiatan belajar tidak sesuai dengan lingkungan belajar. Kegiatan belajar dalam strategi kognitif merupakan kemampuan untuk merencanakan, memantau, dan mengatur pembelajaran tidak sesuai dengan lingkungan pembelajaran daring yang merupakan tempat yang dioptimalkan untuk belajar mandiri.

Penelitian ini sejalan dengan penelitian yang dilakukan oleh (Ayodele \& Olalekan, 2017) hasil menunjukkan bahwa model pembelajaran kolaboratif tidak memengaruhi kinerja siswa. Hal ini disebabkan bahwa kurangnya siswa berkolaborasi dalam pembelajaran. Berawal dari pembentukan kelompok yang heterogen, siswa cenderung enggan bergabung dengan siswa yang tidak terlalu akrab dengan mereka dan mereka hanya ingin berkelompok dengan memiliki kedekatan. Kasus tersebut dapat menghambat berjalannya proses pembelajaran. Interaksi yang kurang berjalan dengan baik disebabkan siswa yang tidak memiliki rasa persatuan dan kesatuan dalam ruang kelompok sehingga memungkinkan terjadi kesulitan dalam mendorong siswa untuk berkolaborasi.

Penelitian ini melaksanakan pembelajaran dengan menggunakan model kolaboratif berbasis masalah tidak berpengaruh terhadap kepuasan belajar siswa. Hal ini disebabkan karena sejumlah faktor yang ditemukan dalam pembelajaran. Faktor yang menyebabkan ketidakpuasan siswa dalam belajar adalah kurang terjalinnya kolaboarasi antar siswa dan kurang tercapainya kegiatan belajar terutama yang memerlukan keterampilan pemecah masalah. Faktor tersebut yang menjadi kebutuhan siswa dalam belajar kurang terpenuhi.

Hasil temuan ini terdapat lima faktor penyebab tidak berpengaruhnya model kolaboratif berbasis masalah terhadap kepuasan belajar dalam pembelajaran. Pertama, pembelajaran masih berjalan satu arah yaitu dari guru kepada siswa. Salah satu lingkungan belajar di sekolah yang dominan adalah kualitas pengajaran (Sudjana, 2013). Saat proses pembelajaran berlangsung guru model yang mengajarkankan dalam pembelajaran kepada siswa memiliki kualitas pengajaran yang baik seperti penyampaian materi yang mudah dipahami, kreatif dalam penggunaan media, mencairkan kondisi yang beku dengan sedikit candaan dan lain sebagainya. Namun, guru model dalam penelitian ini masih memegang kendali sepenuhnya atau dapat dikatakan pembelajaran terstruktur. Keberadaan guru sangat penting dalam pembelajaran dan menjadi salah satu faktor instrumental yang dapat berpengaruh dalam kegiatan pembelajaran (Nasution, 1998). 
Kedua, siswa tertinggal pelajaran. Dalam hal ini kurang terlaksananya proses pembelajaran sehingga siswa terlambat mendapatkan materi. Pelaksanaan pembelajaran dengan model kolaboratif berbasis masalah memerlukan pengetahuan yang telah miliki dan pengetahuan saat ini. Pada saat proses pembelajaran banyak sekali materi pembelajaran yang tertinggal sehingga sulitnya siswa diskusi mengenai suatu topik pembahasan. Guru melakukan penyampaian materi kembali yang belum didapatkan siswa sehingga siswa mendapat materi terdahulu sebagai bahan pengetahuan untuk membantu diskusi. Dalam mengembangkan pemahaman awal, sebuah diskusi eksplisit tentang komitmen instruktur untuk belajar kolaboratif untuk menciptakan iklim yang diinginkan. Penyampaian materi terdahulu sebagai bahan awal memulai diskusi sebuah topik permasalahan.

Ketiga, kurangnya interaksi yang terjadi dalam pembelajaran. Model kolaboratif didasarkan pada filsafat kontruktivisme sosial dimana interaksi sosial berperan penting dalam perkembangan pengetahuan siswa (Widjajanti, 2010). Pada proses pembelajaran pertukaran ide kurang terjalin antar anggota kelompok sehingga kurang mengkonstruk pengetahuan sebagaimana prinsip model kolaboratif berbasis masalah yang dikemukakan oleh (Theodore, 1999) bahwa interaksi antar siswa dapat terjadinya pertukaran ide sehingga memperkaya pendapat atau gagasan pokok sebagai dasar pembangunan pengetahuan mereka. Penyebab kurangnya terjalin interaksi karena siswa belum mendapatkan pengetahuan atau pemahaman dari materi terdahulu yang seharusnya telah dikuasai dan kurangnya kegiatan keterampilan berpikir pemecah masalah dan bahkan sering terjadi proses pembelajaran yang tidak terlaksana sehingga minimnya minat siswa dalam belajar.

Keempat, kurang terjalinnya kolaboarasi antar siswa. Penekanan dalam model ini yaitu pemahaman yang dibangun dengan kolaborasi. Seperti yang telah disebutkan sebelumnya bahwa siswa kurang berinteraksi dalam pembelajaran dengan demikian siswa kurang berpartisipasi secara aktif dalam berkolaborasi. Karena tidak ada kolaborasi maka tidak ada interaksi sosial yang terjadi. Interaksi dilakukan secara kolaborasi oleh siswa dalam kelompok. Pembelajaran kolaboratif memberikan siswa rasa yang lebih kuat terhadap pengetahuan termasuk mempelajari kehidupan sosial dan belajar fenomena sosial melalui kegiatan berkolaborasi (Council, 2017). Oleh karena itu, siswa tidak turut serta dalam kolaborasi berarti tidak ada pemahaman yang dibangun sehingga kebutuhan siswa akan perkembangan kognitif tidak terpenuhi.

Kelima, kurang tercapainya kegiatan belajar terutama yang memerlukan keterampilan pemecah masalah. Kegiatan beajar yang membutuhkan keterampilan berpikir pemecah masalah merupakan hal yang utama dalam melaksanakan pembelajaran dengan model kolaboratif berbasis masalah. Dalam proses pembelajaran siswa kurang berpartisipasi aktif dalam kegiatan memecahkan permasalahan sehingga pengalaman belajar kurang dialami oleh siswa dan belum memenuhi kebutuhan akan perkembangan pengetahuannya. Kebutuhan siswa akan belajarnya yang belum terpenuhi mengakibatkan ketidakpuasan terhadap belajarnya. Kepuasan belajar akan tampak pada siswa jika mereka mengalami pembelajaran sehingga adanya kebutuhan belajar yang terpenuhi.

\section{Dinamika Kelas}

Hasil temuan ini bahwa tidak berpengaruh model kolaboratif berbasis masalah terhadap kepuasan belajar, tetapi penggunaan model kolaboratif berbasis masalah ini ternyata dapat mengubah dinamika kelas dalam proses pembelajaran. Dinamika kelas yang terjadi merupakan manfaat yang dapat dirasakan dalam rangka pengguanaan model kolaboratif berbasis masalah. Seperti yang dikatakan oleh (Council, 2017) bahwa pembelajaran kolaboratif perlu mengetahui dan menguasai dinamika kelompok (dinamika kelas) sebagai proses emosional dalam pembelajaran dan dampak siswa yang bekerja dalam kelompok. Dengan demikian, pembelajaran kolaboratif dapat mengubah kondisi kelas sehingga guru perlu memahami setiap peruahan yang terjadi selama proses pembelajaran.

Dinamika kelas yang terjadi ditandai dengan adanya pada peningkatan hasil belajar siswa. Peningkatan yang terjadi dijelaskan berdasarkan penghitungan statistik dan hasil observasi kegiatan siswa dalam pembelajaran. Berdasarkan penghitungan statistik, diketahui bahwa kelompok eksperimen memperoleh rata-rata hasil pretest 13,97 dan rata-rata hasil posttest 16,19. Dengan demikian, hasil menunjukkan bahwa kelompok eksperimen mengalami peningkatan sebesar 37\% dengan kualifikasi sedang. Hal tersebut menandakan bahwa pembelajaran dengan mengaplikasikan model kolaboratif berbasis masalah mengubah dinamika kelas yang ditandai dengan peningkatan hasil belajar. Hal tersebut selaras dengan hasil temuan oleh (Chandra, 2015) hasil menunjukkan bahwa pembelajaran kolaboratif dapat meningkatkan hasil belajar siswa.

Pemaparan peningkatan hasil belajar berdasarkan penghitungan statistik dan hasil observasi tersebut belum dapat menjelaskan pengambaran dinamika kelas maka perlu dijelaskan mengenai dinamika kelas yang terjadi dalam pembelajaran. Pembelajaran dengan menggunakan model kolaboratif dimulai dengan para siswa duduk dan dapat melihat setiap wajah siswa yang lain (Writing, 2017). Dinamika kelas terjadi mulai dari perubahan bentuk duduk kelas yang semula bentuk satu arah yaitu seluruh siswa menghadap ke depan kelas menjadi bentuk duduk berhadapan satu sama lain sehingga dapat memudahkan siswa dalam kegiatan berdiskusi kelompok. 
Kegiatan diskusi kelompok melibatkan partisipasi aktif siswa sehingga interaksi dapat berjalan. Dinamika kelas yang terjadi ketika diskusi kelompok dimana siswa turut serta untuk mulai berinteraksi dengan mengajukan pertanyaan untuk mengundang siswa lain untuk menjawab. Suatu pertanyaan yang diajukan tidak hanya melibatkan mereka dalam pemikiran produktif, tetapi juga dapat memberikan informasi berharga kepada anggota diskusi (Davidson \& Major, 2014).

Dinamika kelas yang nampak pada siswa ketika awalnya siswa terlihat tidak ada kepedulian dalam tugas belajar menjadi mulai menyadari adanya tanggung jawab dalam belajar. Model kolaboratif berbasis masalah yang mengondisikan siswa untuk mencari solusi atau memecahkan suatu permasalahan secara kolaborasi. (Davidson \& Major, 2014) mengungkapkan bahwa salah satu tujuan pembelajaran kolaboratif adalah siswa belajar bertanggung jawab untuk bekerja bersama. Keberhasilan belajar tergantung pada keberhasilan kelompok maka siswa mencoba untuk memecahkan permasalahan secara kolaborasi sebagai tugas pembelajaran yang harus diselesaikan.

\section{SIMPULAN}

Kesimpulan dari hasil temuan terkait pengaruh model kolaboratif berbasis masalah terhadap kepuasan belajar siswa sekolah dasar.

Pertama, tidak berpengaruh yang signifikan dari penerapan model kolaboratif berbasis masalah terhadap kepuasan belajar siswa sekolah dasar. Hasil uji hipotesis menunjukkan bahwa perolehan signifikansi p-level 0,089 lebih besar dari 0.05 $(0,089>0.05)$. Adapun perbandingan nilai rata-rata kelompok eksperimen 16,19 lebih besar dari perolehannilai rata-rata kelompok kontrol 15,42 dan simpangan baku kelompok eksperimen 3,618 lebih heterogen dibandingkan dengan simpangan baku kelompok kontrol 1,478. Faktor penyebab model kolaboratif berbasis masalah tidak memiliki pengaruh terhadap kepuasan belajar yaitu kurang terjalinnya kolaborasi antar siswa dan kurang tercapainya kegiatan belajar terutama yang memerlukan keterampilan pemecah masalah sehingga belum terpenuhi kebutuhan siswa akan belajar.

Kedua, penerapan model kolaboratif berbasis masalah memiliki sejumlah manfaat yang dapat dirasakan dalam pembelajaran. Manfaat yang dirasakan dapat mengubah dinamika kelas. Dinamika kelas yang terjadi yaitu adanya pada peningkatan kepuasan siswa dan aktivitas belajar siswa.

Berdasarkan pembahasan penelitian dapat dirumuskan dua saran. Kedua saran tersebut untk gur dnpeneliti selanjutnya, yakni sebagai berikut. Pertama, guru diharapkan dapat melaksanakan pembelajaran dengan menggunakan model kolaboratif berbasis masalah dengan memperhatikan prinsip-prinsip yang terkandung dalam model. Model ini memberikan peluang untuk meraih kesuksesan dalam belajar dengan menerapkan kegiatan belajar yaitu melibatkan interaksi aktif siswa secara berkolaborasi. Pelaksanaan pembelajaran perlu berupaya semaksimal mungkin untuk mengolah waktu yang cukup dalam menerapkan model pembelajaran dan berupaya agar terciptanya lingkungan belajar yang mendorong siswa untuk lebih saling berinteraksi, sehingga dapat terlaksananya pembangunan pengetahuan dengan baik sesuai yang telah direncanakan. Penerapan model kolaboratif berbasis masalah diharapkan dapat menjadi salah satu upaya dalam memberdayakan kemampuan berpikir pemecah masalah dan keterampilan berkolaborasi pada siswa. Kedua, peneliti selanjutnya diharapkan untuk meneliti model kolaboratif dengan pendekatan yang tepat sesuai dengan kondisi atau karakteristik masalah yang ditemukan. Pendekatan yang tepat sasaran dapat memotivasi siswa belajar, mendorong siswa berinteraksi, berani berpendapat, dan percaya diri mengungkapkan gagasan pokok dalam diskusi kelompok.

\section{DAFTAR RUJUKAN}

Ayodele, M., \& Olalekan, H. (2017). Effects of Collaborative Learning Styles on Performance of Students in a Ubiquitous Collaborative Mobile Learning Environment. Contemporary Educational Technology, 8(3), 268-279.

Balta, N. (2017). The Effect of Student Collaboration in Solving Physics Problems Using an Online Interactive Response System. European Journal of Educational Research, 6(3), 385-394. https://doi.org/10.12973/eu-jer.6.3.385

Barkley, E. (2016). Collaborative Learning Techniques: Teknik-Teknik Pembelajaran Kolaboratif. Bandung: Nusa Media

Chandra, R. (2015). Collaborative Learning for Educational Achievement. IOSR Journal of Research \& Method in Education (IOSR-JRME), 5(3), 2320-7388. https://doi.org/10.9790/7388-05310407

Davidson, N., \& Major, C. H. (2014). Boundary Crossings : Cooperative Learning, Collaborative Learning, and ProblemBased Learning. Journal of Excellence in Collge Teaching, 25(3\&4), 7-55. https://doi.org/10.2307/257019

Firoozi, M. R., Kazemi, A., \& Jokar, M. (2017). The role of socio-cognitive variables in predicting learning satisfaction in smart schools. International Electronic Journal of Elementary Education, 9(3), 613-626.

Fleischmann, K., \& Hutchison, C. (2012). Creative exchange: An evolving model of multidisciplinary collaboration. Journal of Learning Design, 5(1), 23-31. https://doi.org/10.5204/jld.v5i1.92

Globe, F. (1999). Ahzab Ketiga: Psikologi Humanistik Abraham Moslow. Yogyakarta: Kanisius.

Hyun, J., Ediger, R., \& Lee, D. (2017). Students' Satisfaction on Their Learning Process in Active Learning and Traditional Classrooms. International Journal of Teaching, 29(1), 108-118. 
Nasution, N. (1998). Materi Pokok Psikologi Pendidikan. Jakarta: Direktorat Jendral Pembinaan Kelembagaan Agama Islam dan Universitas Terbuka.

Sopiatin, P. (2010). Menejemen Belajar Berbasis Kepuasan Peserta Didik. Bogor: Graha Indonesia.

Sudjana, N. (2013). Dasar-Dasar Proses Belajar Mengagajar. Bandung: Sinar Baru Algensindo.

Sudjana, N. (2014). Penilaian Hasil Proses Belajar Mengajar. Bandung: Remaja Rosdakarya.

Sulistyawati, N., \& Zuhdi, D. (2016). Implementasi Teknik Pembelajaran Kolaboratif dengan Variasi Media untuk Peningkatan Hasil Belajar di SMPN 2 Kalijambe. Harmoni Sosial : Jurnal Pendidikan IPS, 3(1), 50-61. 10.21831/hsjpi.v3i1.9694

Theodore, P. (1999). Collaborative Versus Cooperative Learning -a Comparison of the Two, 1-3. Retrieved from http://www.capecod.net/ TPanitz/Tedspage

Uduafemhe, M. E. (2015). Comparative Effects of Scaffolding and Collaborative Instructional Approaches on Secondary School Students' Psychomotor Achievement in Basic Electronics in North-Central Nigeria. IOSR Journal of Engineering (IOSRJEN), 05(06), 2250-3021.

Ünal, E., \& Çakir, H. (2017). Students' Views about the Problem Based Collaborative Learning Environment Supported by Dynamic Web Technologies. MOJET: The Malaysian Online Journal of Educational Technology, 5(2), 1-19.

Warsono. (2016). Pembelajaran Aktif Teori dan Asesmen. Bandung: Remaja Rosdakarya.

Wedi, A. (2016). Konsep dan Masalah Penerapan Metode Pembelajaran: Upaya Peningkatan Mutu Pembelajaran melalui Konsistensi Teoretis-Praktis Penggunaan Metode Pembelajaran. Edcomtech: Jurnal Kajian Teknologi Pendidikan, 1(1), 21-28. 